\title{
Frequency of Metallo- $\beta$-Lactamases and Carbapenemase Enzymes in Clinical Isolates of Pseudomonas aeruginosa
}

\author{
Masoumeh Beig1, Mohammad Taheri², Mohammad Reza Arabestani3,* (iD) \\ ${ }^{1}$ MSc in Microbiology, Hamadan University of Medical Sciences, Hamadan, Iran \\ ${ }^{2}$ Assistant Professor, Department of Microbiology, Hamadan University of Medical Sciences, Hamadan, Iran \\ ${ }^{3}$ Associate Professor, Nutrition Health Research Center, Hamadan University of Medical Sciences, Hamadan, Iran \\ * Corresponding Author: Mohammad Reza Arabestani, Nutrition Health Research Center, Hamadan University of Medical \\ Sciences, Hamadan, Iran.Email: mohammad.arabestani@gmail.com
}

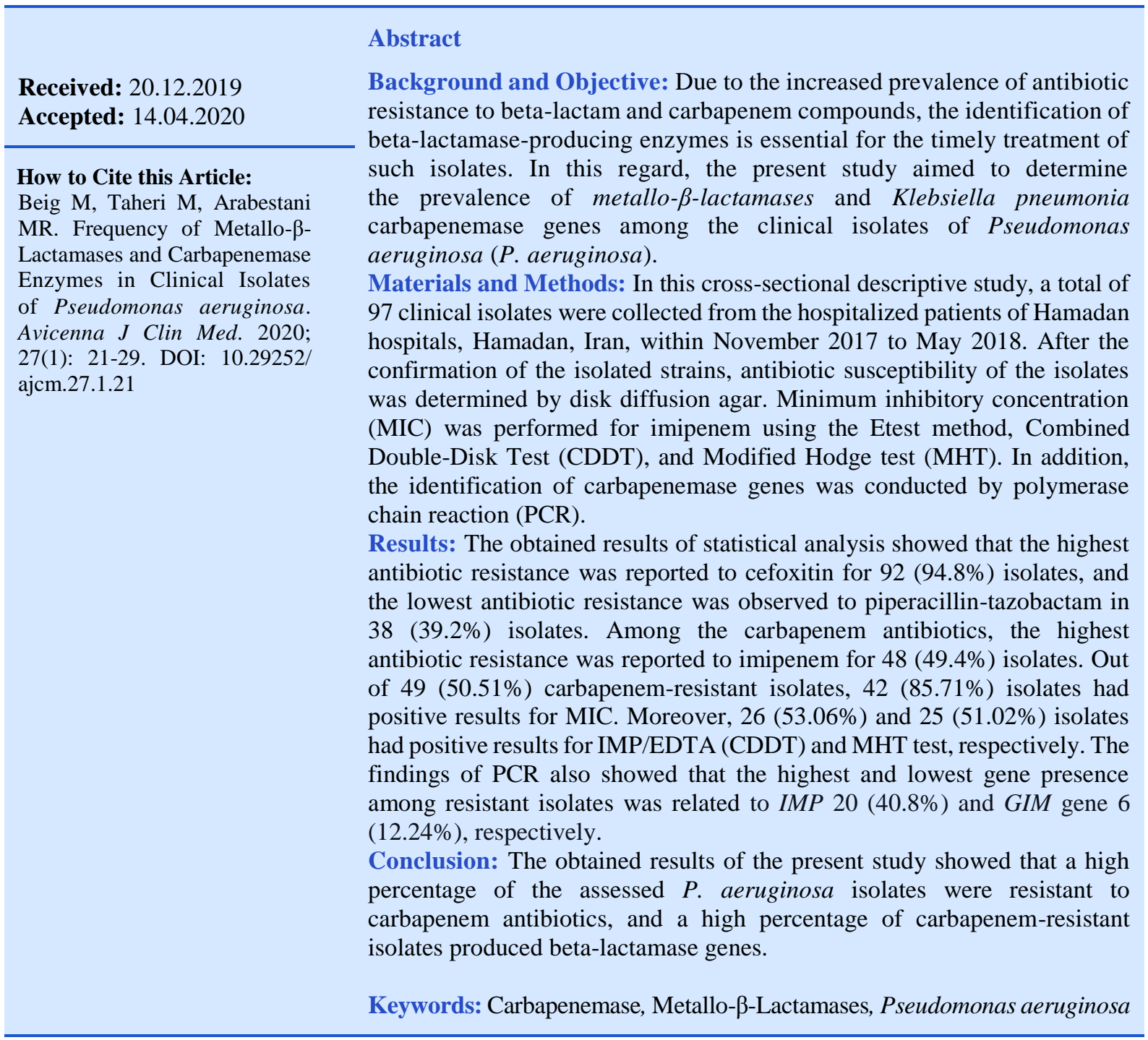


ارزيابى فراوانى آنزيمهاى متالوبتالاكتاماز و كاربإنماز در ايزولههاى كلينيكى

\title{
سودوموناس آثُوزينوزا
}

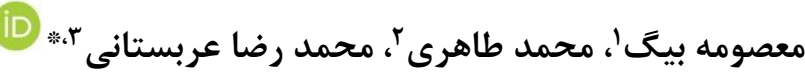 \\ ' كارشناسى ارشد ميكروبشناسى، دانشكاه علوم يزشكى همدان، همدان، ايران

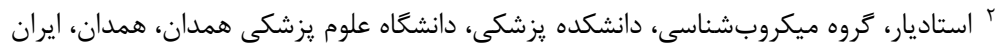

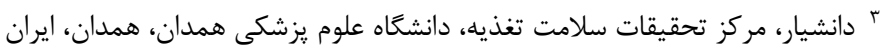

* *ويسنده مسئول: محمد رضا عربستانى، مركز تحقيقات سلامت تغذيه، دانشكاه علوم يزشكى همدان، همدان، ايران. ايميل:mohammad.arabestani@gmail.com

\begin{tabular}{|c|c|}
\hline 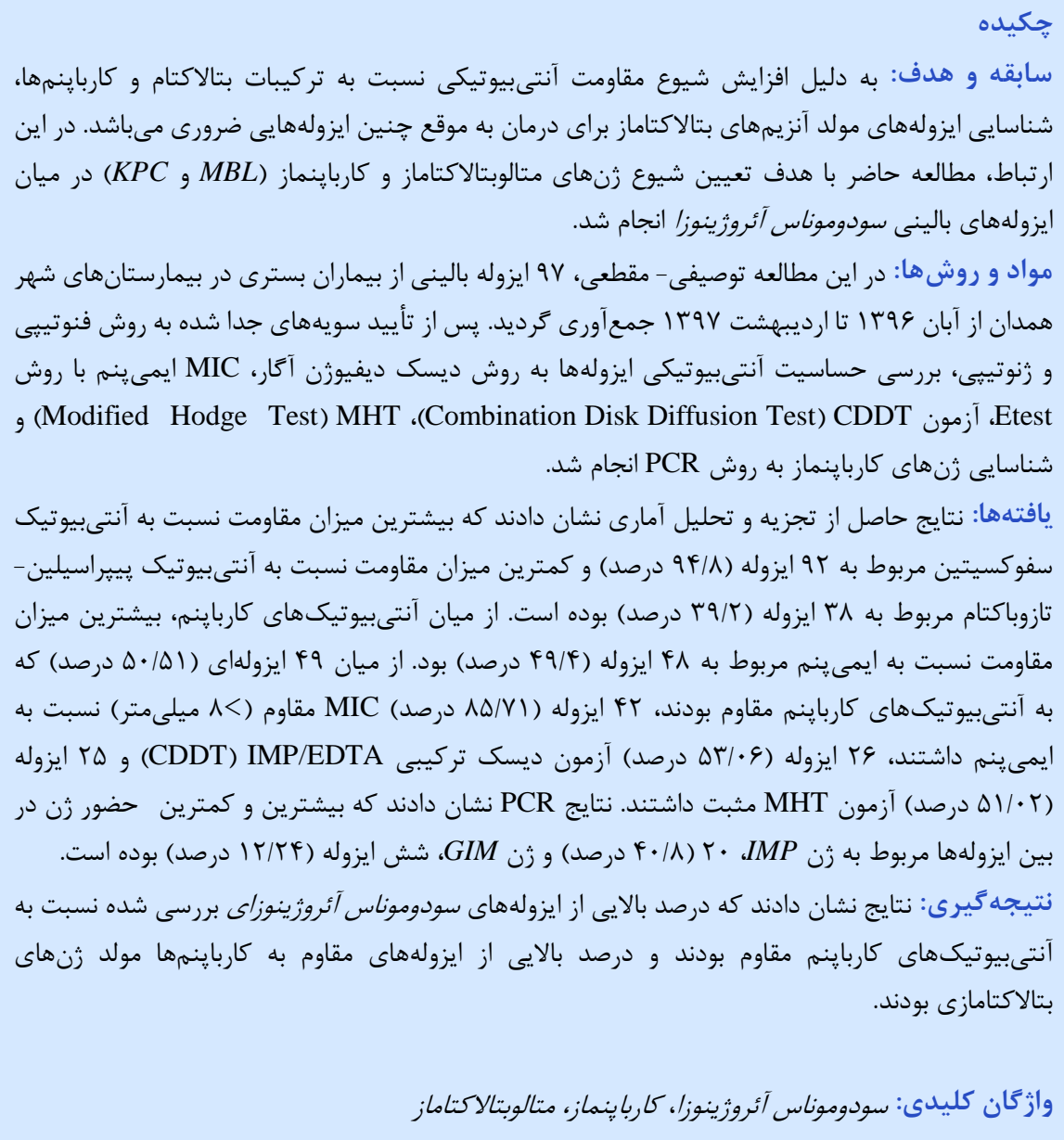 & 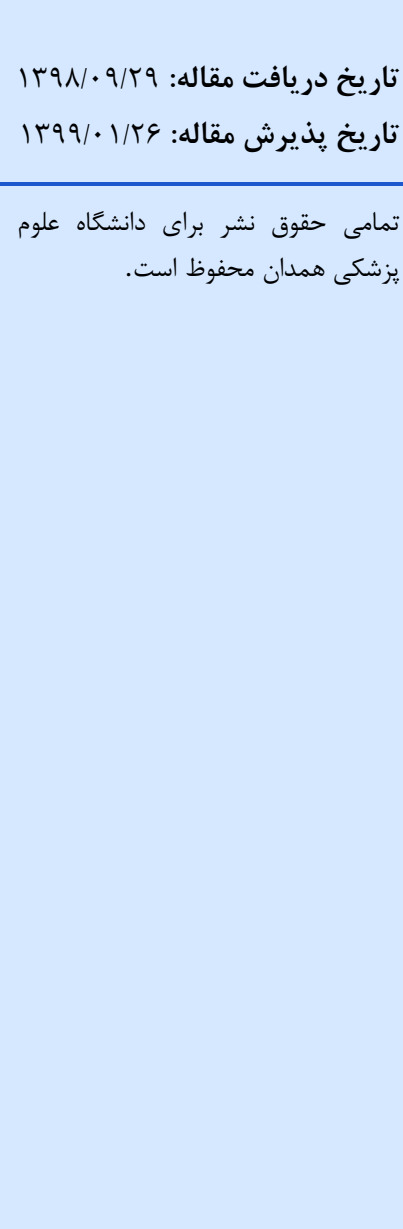 \\
\hline
\end{tabular}

گزارش شده است. مكانيسمهاى مقاومت به كارباينمها به دلايلى

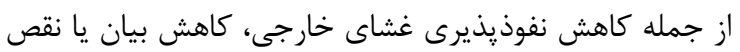

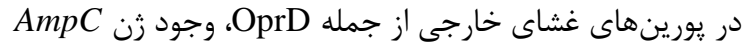

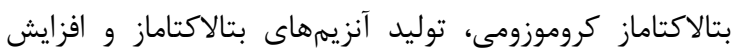

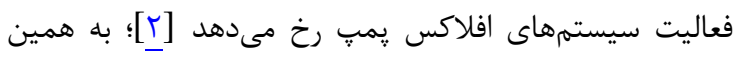
دليل شناسايى سريع و دقيق سويههاى توليدكننده آنزيمهاى
سودوموناس آئروزينوزا باكترى گرم منفى و و پاتوزن فرصتطلبى است كه عامل عفونتهاى مهمم در افراد با ضعف كنفي

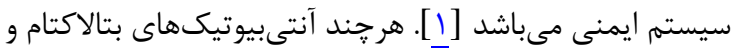

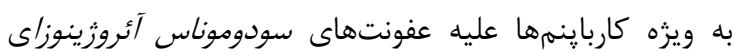
(Multi Drug Resistant) MDR آنتىبيوتيكهاى كارباينه از سراسر جهان در اين باكترىها 
متالوبتالاكتاماز از مهار كنندهها استفاده مىكردد. از معمولترين

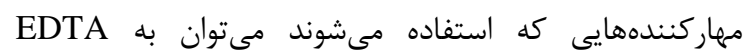
(Ethylene Diamine Tetra Acetic Acid)

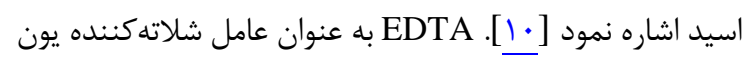

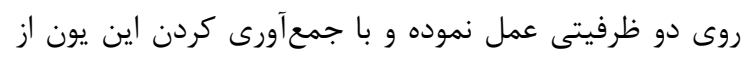

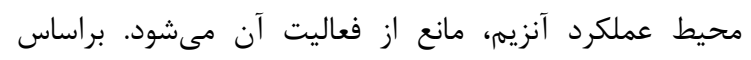

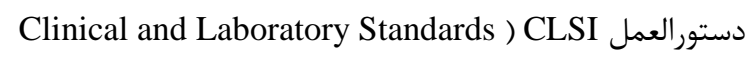

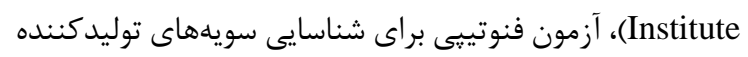
آنزيم كارباينماز، MHT معرفى شده است.

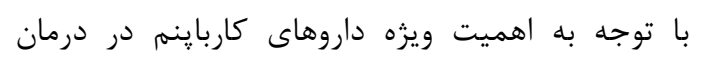

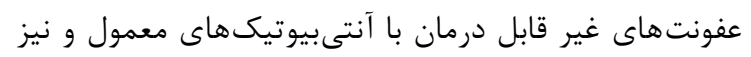

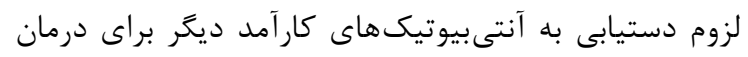

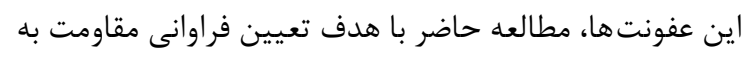

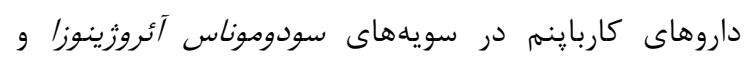

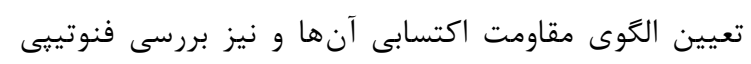

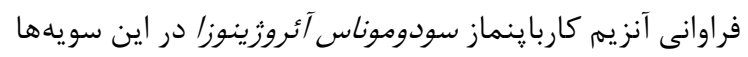

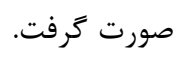

\section{مواد و روشها}

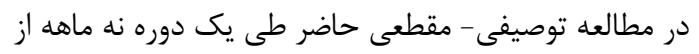

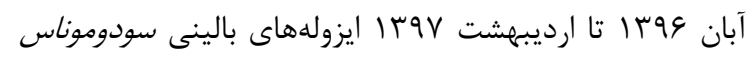



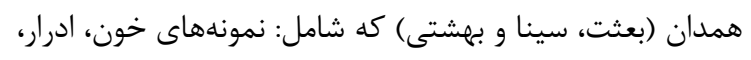

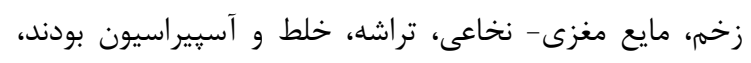

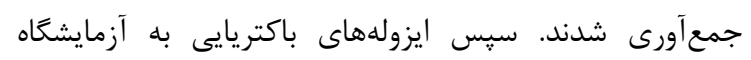

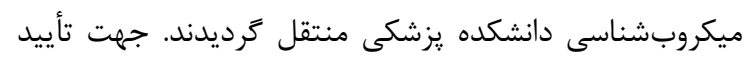

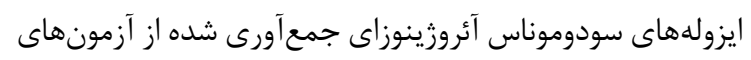

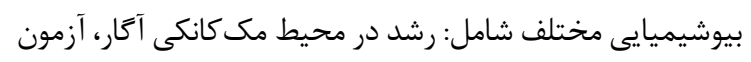

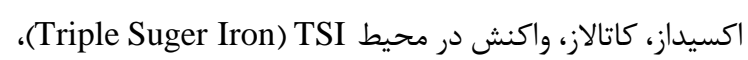

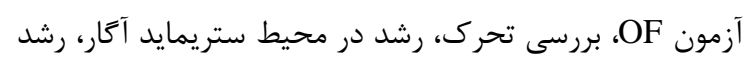

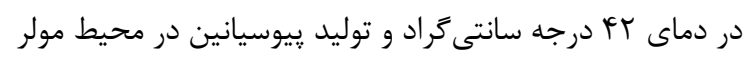
هينتون آكار استفاده شد.

\section{آزمون تعيين حساسيت آنتىبيوتيكى در /يزولهاى باكتريا يبى}

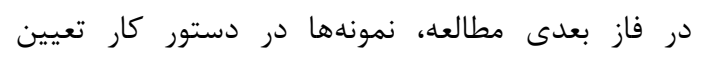

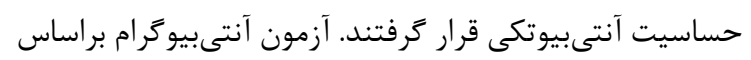



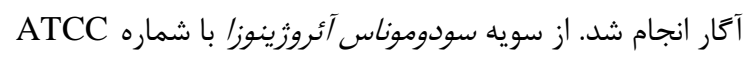

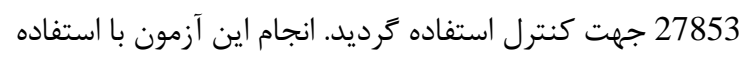

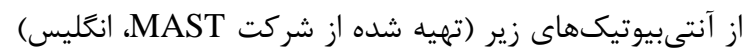
صورت كرفت [111]

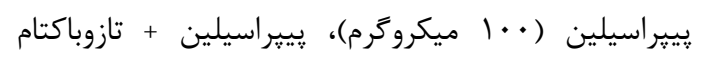

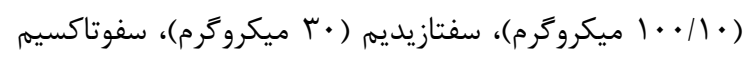

كارباينماز براى درمان مناسب و جلوكيرى از كَترش

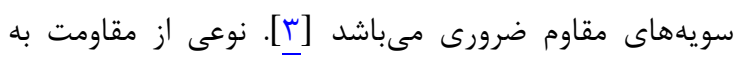

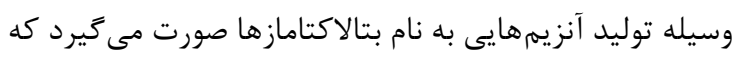

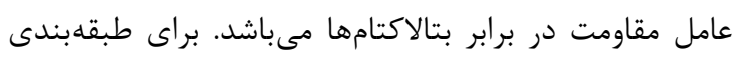

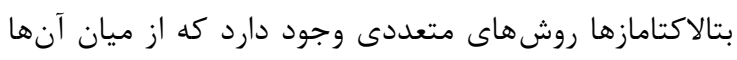

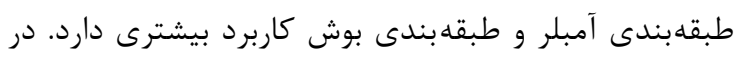



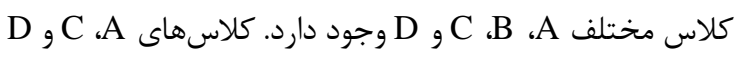

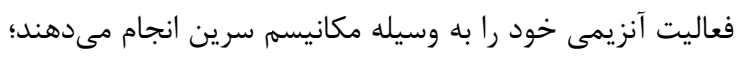

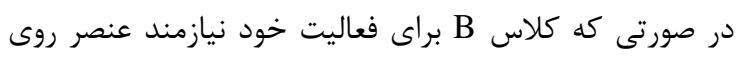

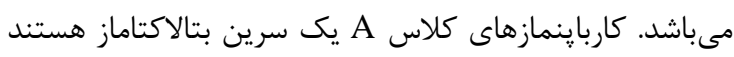

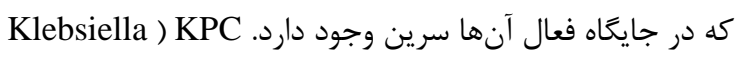
(Pneumoniae Carbapenemase

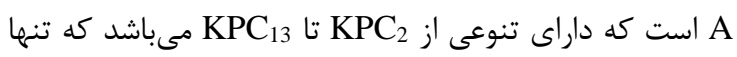

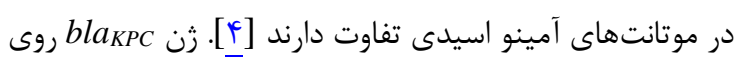

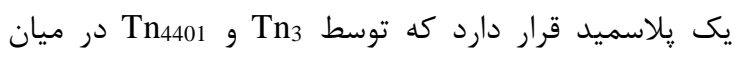

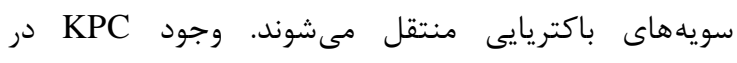

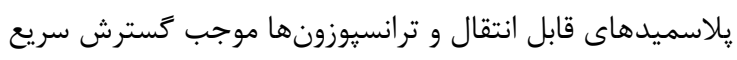

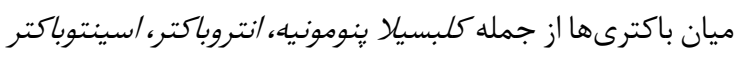

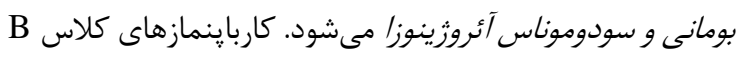

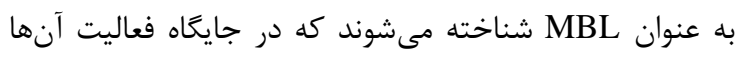

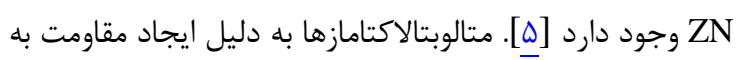

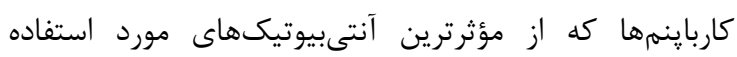

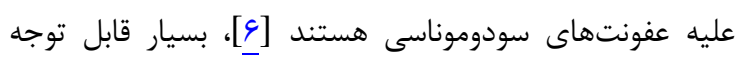



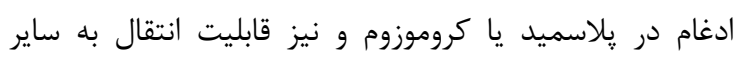

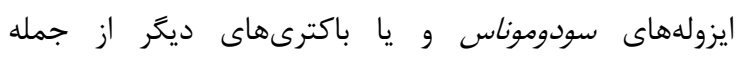

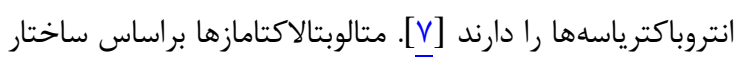

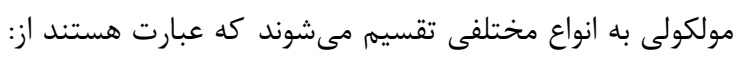
(Verona Imipenemase) VIM ،Imipenemase) IMP Sao Paulo ) SPM ،(German Imipenemase) GIM New Delhi) NDM , (6metallo-Beta-Lactamase در كه از ميان آنها Metallo-Beta-Lactamase

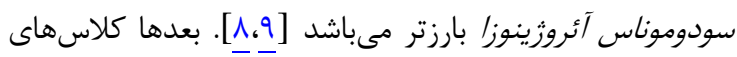

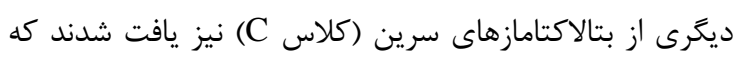

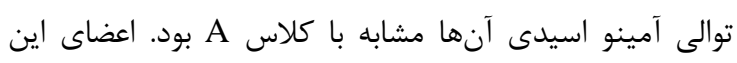

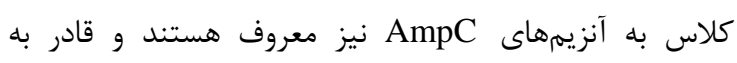



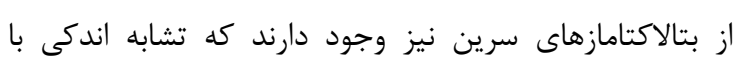

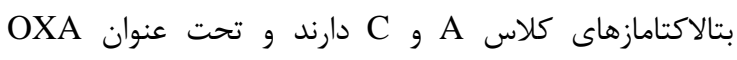

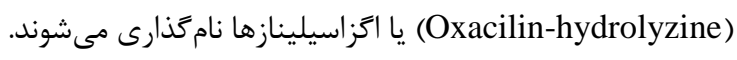

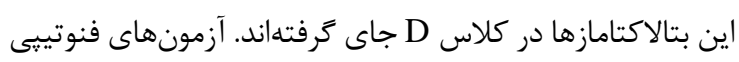

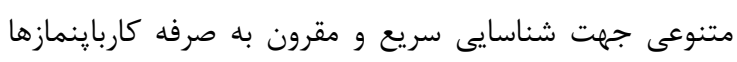

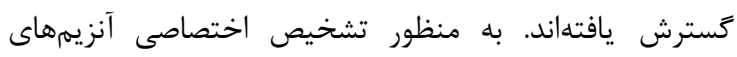


ايزولههاى سودوموناس آئروزينوزا كه به آنتىبيوتيكهاى كارباينه

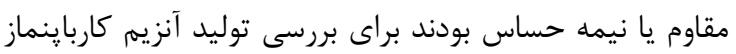

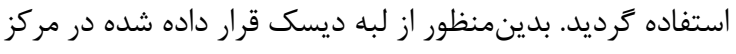

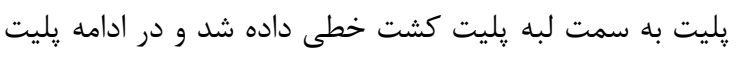



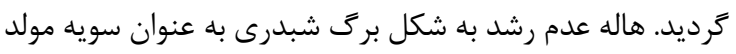

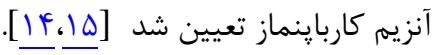
در اين مطالعه از كلبسيلا ينومونيه استاندارد با شماره

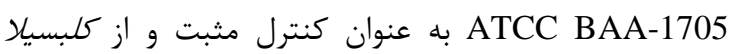

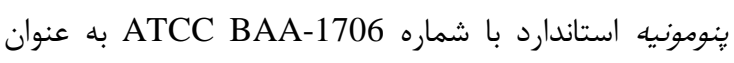
كنترل منفى (تهيه شده از مركز تحقيقاتى انستيتو ياستور ايران)

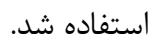

\section{استخراج DNA انجام PCR}

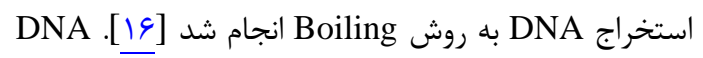

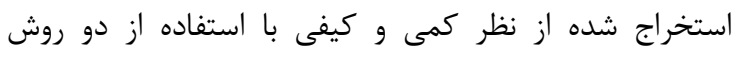

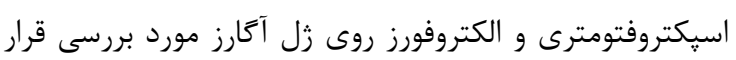

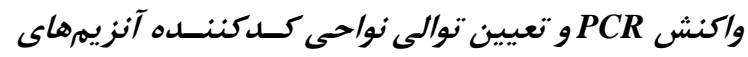
كاربا ينماز

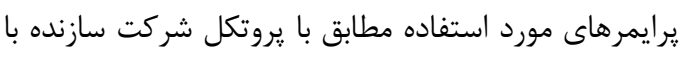

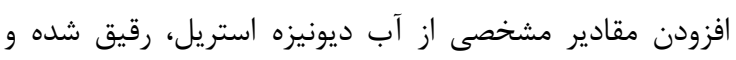

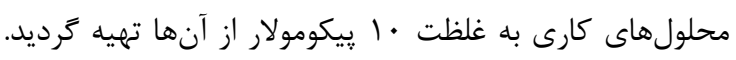

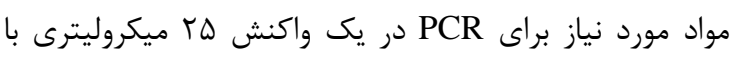

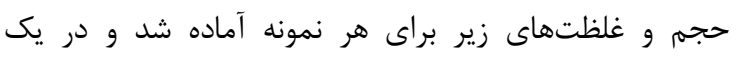

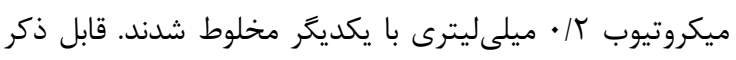

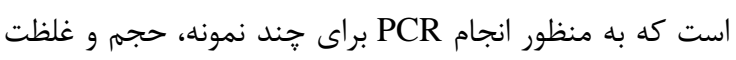

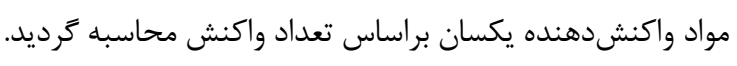

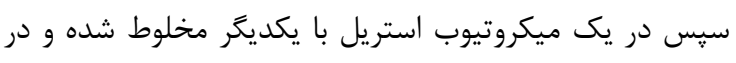

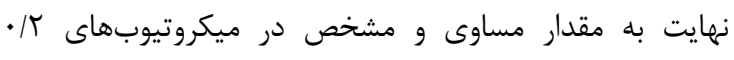

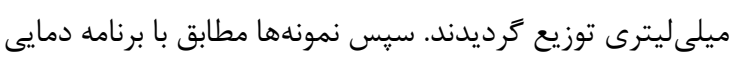

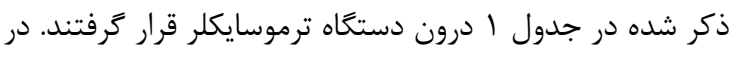

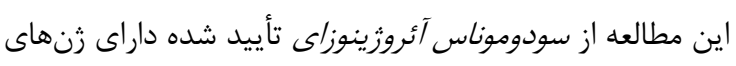

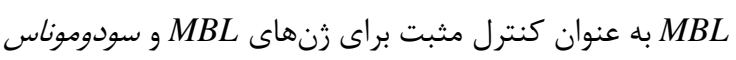

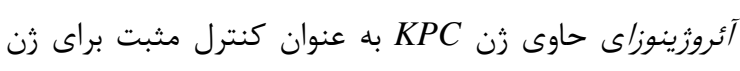
استفاده شد (تهيه شده از مركز تحقيقاتى انستيتو ياستور

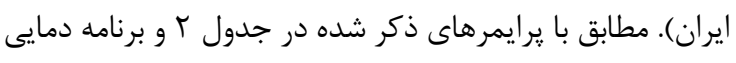

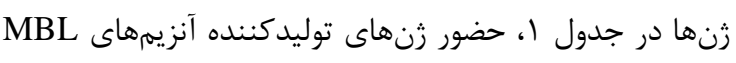
KPC در ايزولههاى باكتريايى با استفاده از روش

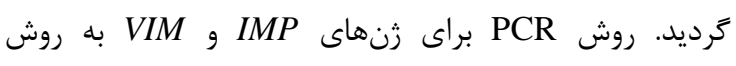

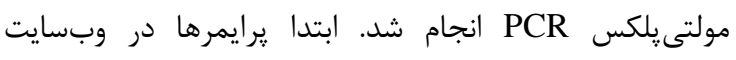

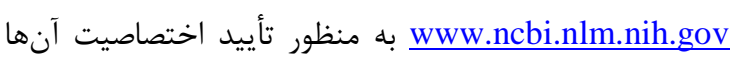
براى جنس سودوموناس كونه آئروزينوزا BLAST شدند. تأيد اختصاصيت آنها

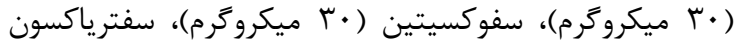

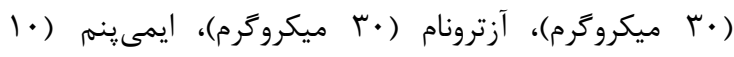

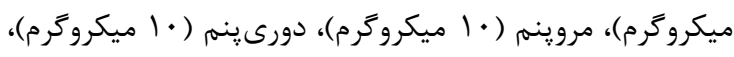

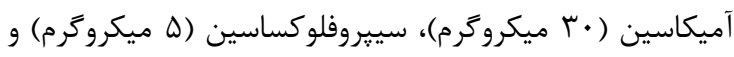

$$
\text { تتراسايكلين (•r ميكروكرم). (- ميكروم)، }
$$

\section{نعيين حداقل غلظت مهارى (MIC)}

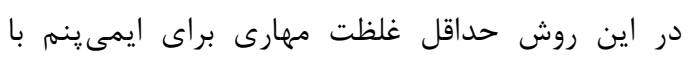

استفاده از نوار Etest (شركت MAST، انتخليس) تعيين شد.

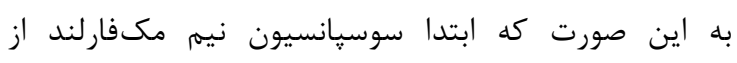



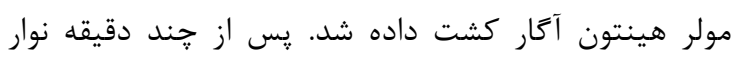
Etest



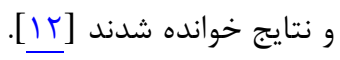

\section{آزمونهاى فنوتيبى جهت شناسا يیى آنزيمهاى كاربا بنماز

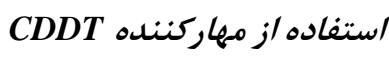

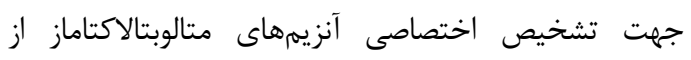

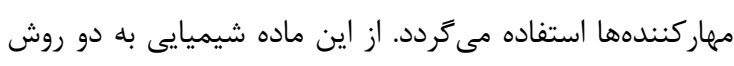

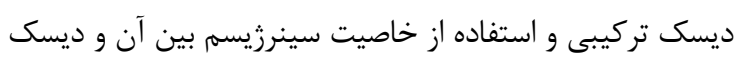

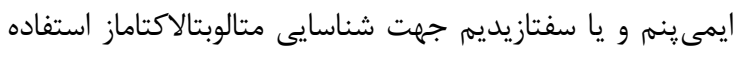

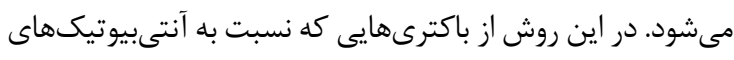

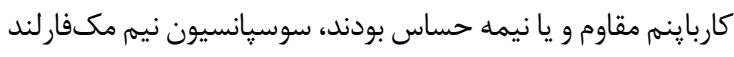

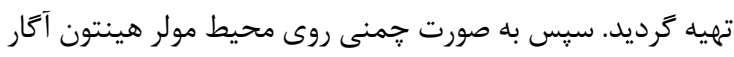

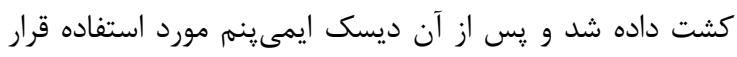

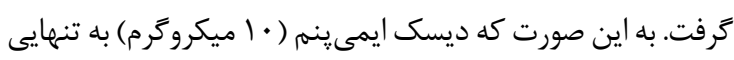

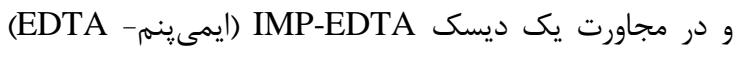

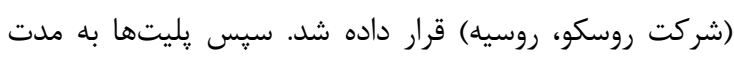

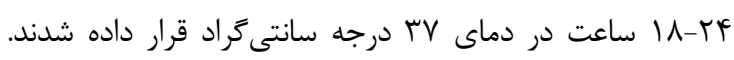

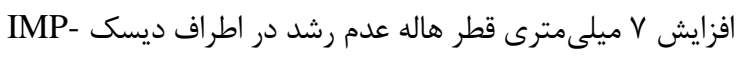

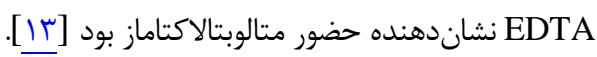

\section{(Modified Hodge Test)MHT آزمون}

آزمون MHT براى بررسى وجود آنزيم كارباينماز مطابق با

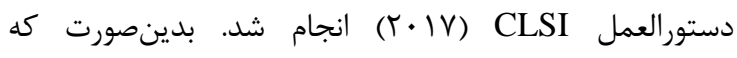

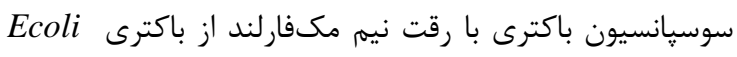

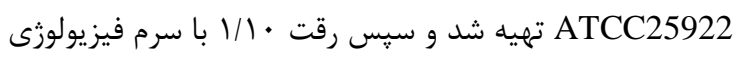

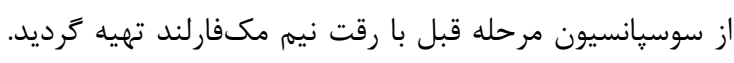

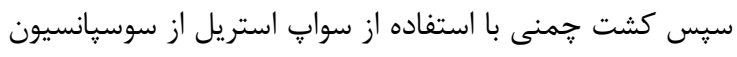

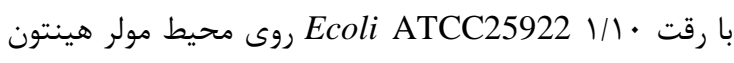

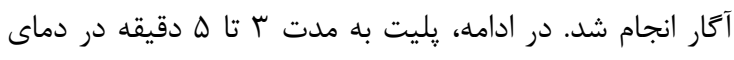

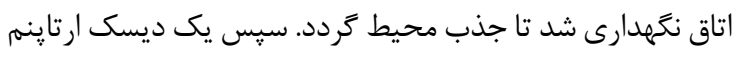

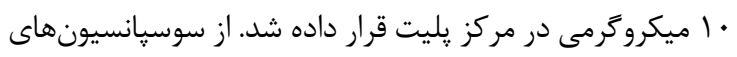


جدول ا: برنامه دمايى PCR رنهاى vim و vim ،

\begin{tabular}{|c|c|c|c|c|c|c|}
\hline ز & دناتوراسيون اوليه & دناتوراسيون & اتصال & طويلسازى & طويلسازى نهايى & سيكل \\
\hline \multirow{2}{*}{$k p c$} & 90 & $9 \Delta$ & $\Delta \varphi$ & VT & VT & \multirow{2}{*}{ r. } \\
\hline & $\Delta \min$ & $1 \min$ & $1 \min$ & $1 \min$ & $\Delta \min$ & \\
\hline \multirow{2}{*}{$v i m$, imp } & $9 \Delta$ & $9 \Delta$ & $\Delta \Delta$ & VT & VT & \multirow{2}{*}{ rd } \\
\hline & $\Delta \min$ & $1 \min$ & $1 \min$ & $1 \mathrm{~min}$ & $\Delta \min$ & \\
\hline \multirow{2}{*}{$\operatorname{sim}$} & 90 & 90 & $\Delta \varphi$ & VT & VT & \multirow{2}{*}{ rd } \\
\hline & $\Delta \min$ & $1 \mathrm{~min}$ & $1 \min$ & $1 \mathrm{~min}$ & $1 \cdot \min$ & \\
\hline \multirow{2}{*}{ spm gim } & 94 & 94 & 9. & VT & VT & \multirow{2}{*}{$r \Delta$} \\
\hline & $1 \cdot \min$ & $r \cdot s$ & $\mathrm{r} \cdot \mathrm{s}$ & $1 \min$ & $\checkmark \min$ & \\
\hline \multirow{2}{*}{$\operatorname{acs} A$} & $9 \Delta$ & 90 & $\Delta \Delta$ & VT & VT & \multirow{2}{*}{ rd } \\
\hline & $\Delta \min$ & $1 \mathrm{~min}$ & $1 \min$ & $\Delta \min$ & $\Delta \min$ & \\
\hline
\end{tabular}

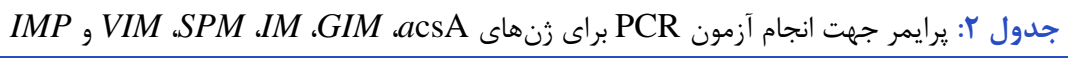

\begin{tabular}{|c|c|c|c|c|}
\hline References & bp & Sequence $\left(5^{\prime}-3^{\prime}\right)$ & Primer & Family \\
\hline$[\underline{\mathrm{IV}}$ & $\Delta \vee \wedge$ & $\begin{array}{c}\text { GAT GGT GTT TGG TCG CAT A } \\
\text { CGA ATG CGC AGC ACC AG }\end{array}$ & $\begin{array}{l}\text { KPC-F } \\
\text { KPC-R }\end{array}$ & $k p c-1$ to $k p c-5$ \\
\hline$[1 \wedge]$ & $1 M 1$ & $\begin{array}{c}\text { GGA ATA GAG TGG CTT AAY TCT C } \\
\text { CCA AAC YAC TAS GTT ATC T }\end{array}$ & $\begin{array}{l}\text { IMP-F } \\
\text { IMP-R }\end{array}$ & $i m p$ \\
\hline$[1 \wedge]$ & rq. & $\begin{array}{l}\text { GAT GGT GTT TGG TCG CAT A } \\
\text { CGA ATG CGC AGC ACC AG }\end{array}$ & $\begin{array}{l}\text { VIM-F } \\
\text { VIM-R }\end{array}$ & vim \\
\hline [19] & rVI & $\begin{array}{l}\text { AAA ATC TGG GTA CGC AAA CG } \\
\text { ACA TTA TCC GCT GGA ACA GG }\end{array}$ & $\begin{array}{l}\text { SPM-1F } \\
\text { SPM-1R }\end{array}$ & $s p m-1$ \\
\hline [19] & $\Delta V \cdot$ & $\begin{array}{l}\text { TAC AAG GGA TTC GGC ATC G } \\
\text { TAA TGG CCT GTT CCC ATG TG }\end{array}$ & $\begin{array}{l}\text { SIM-1F } \\
\text { SIM-1F }\end{array}$ & sim-1 \\
\hline [19] & FV & $\begin{array}{l}\text { TCG ACA CAC CTT GGT CTG AA } \\
\text { AAC TTC CAA CTT TGC CAT GC }\end{array}$ & $\begin{array}{l}\text { GIM-1F } \\
\text { GIM-2R }\end{array}$ & gim \\
\hline$[r \cdot]$ & NTH & $\begin{array}{l}\text { ACCTGGTGTACGCCTCGCTGAC } \\
\text { GACATAGATGCCCTGCCCCTTGAT }\end{array}$ & $\begin{array}{l}\operatorname{acs} A-1 F \\
\operatorname{acs} A-2 R\end{array}$ & $\operatorname{acs} A$ \\
\hline
\end{tabular}

بيمارستانهاى شهر همدان جداسازى گرديد و براساس آزمونهاى تشخيص آزمايشعاهى، لو ايزوله (



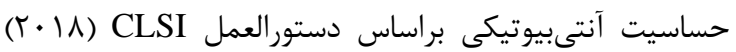

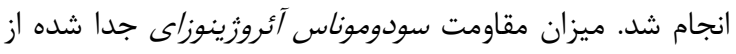

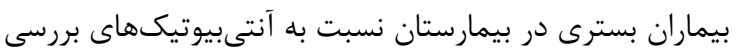
شده در شكل ا نشان داده شده است.



MBL مطالعه از سودوموناس آئروزينوزاى تأييد شده داراى ثنهاى

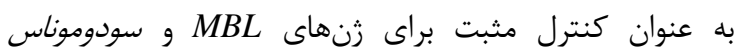

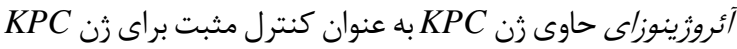
استفاده شد (تهيه شده از مركز تحقيقاتى انستيتو ياستور ايران).

كافتهن جمعآورى / يزولهها و آزمون حساسيت آنتسىبيوتيكى

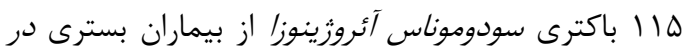

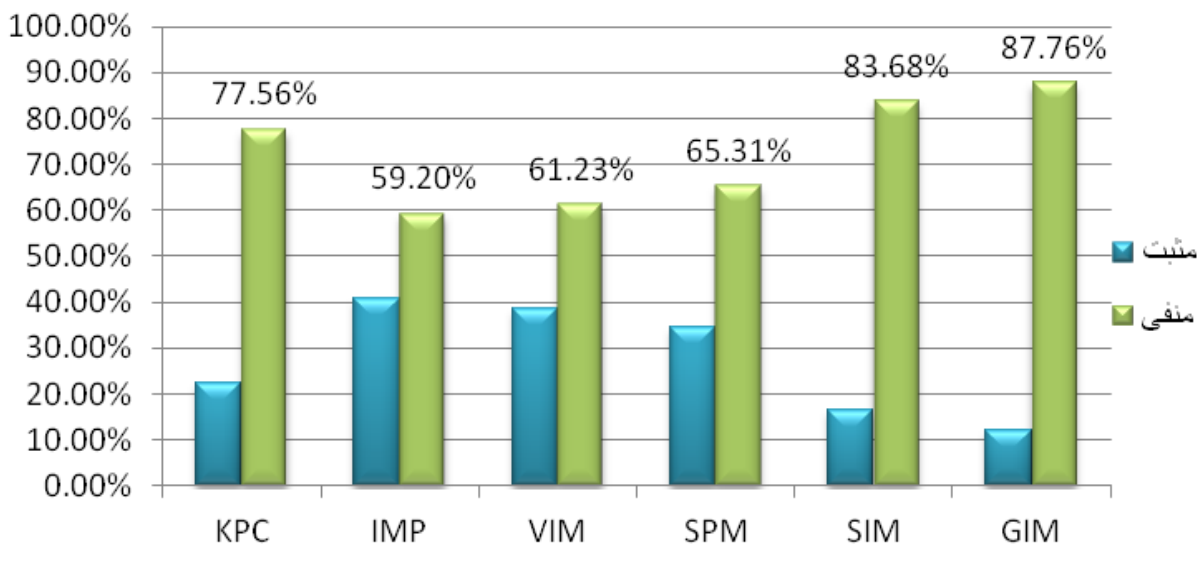

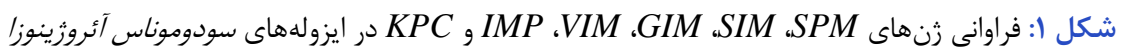






شكل "ب: سويههاى MHT مثبت سودوموناس آئروزينوا

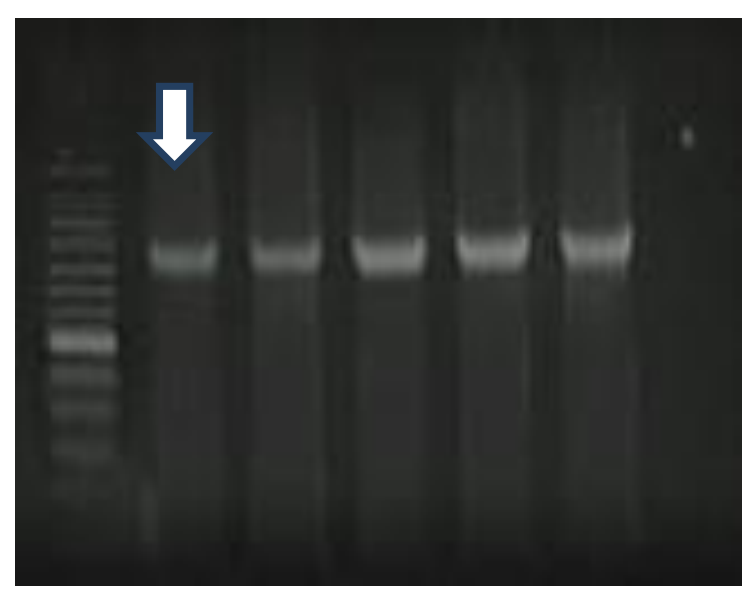

AcsA شكل ₹أ نتيجه الكتروفورز تكثير محصولات زن استاندارد جهت تأييد ايزولههاى سودوموناس آئرورينوزا (AT bp)

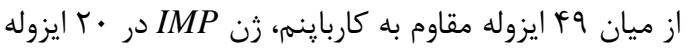



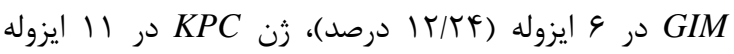

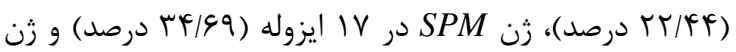

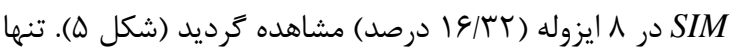

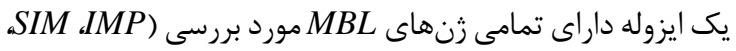
(GIM و VIM SPM

بحث

آنتىبيوتيكهاى كارباينم خط آخر درمان براى بيشتر

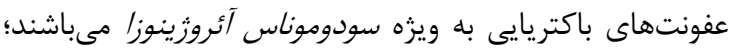

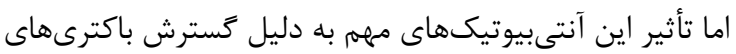

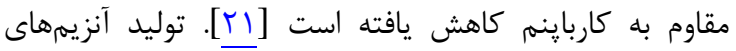
MBL

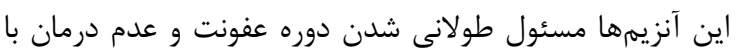

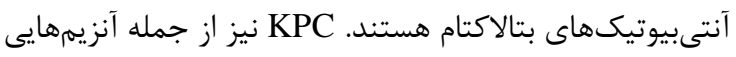
مىباشد كه موجب بىاثر كردن آنتى بيوتيكهاى بتالاكتام به ويزها

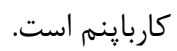

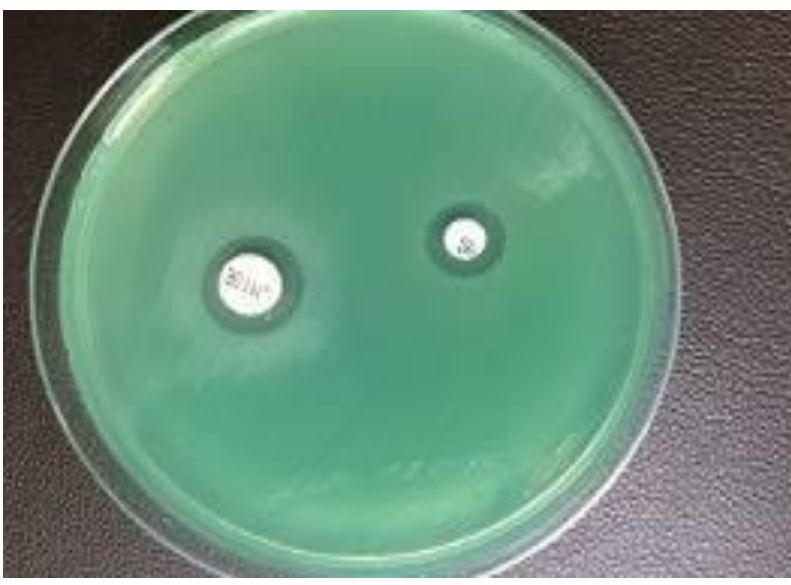

شكل ז: اثر سينرزيسم بين EDTA و ايمىينهم

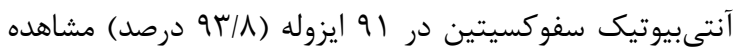

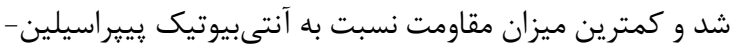

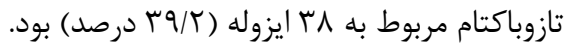

نتايج حاصل /ز تعيين حداقل غلظت مهارى به /يمى ينم

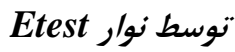

از ميان q ا ايزوله سودوموناس آئروزينوزاى مقاوم و نيمه

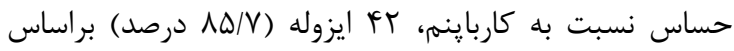

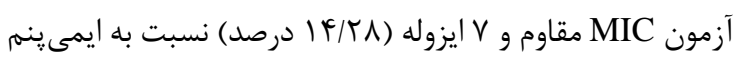

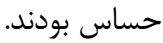

آزمونهاى فنوتيبيى تعيين /يزولههاى مولد آنزيم



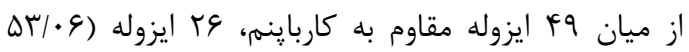

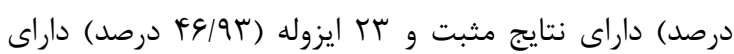
نتايج منفى بودند (شكل ك).

آزمون فنوتييى شناسا يیى /يزولههاى مولد آنزيمر كلبسيلا بنومونيه كاربا بنماز

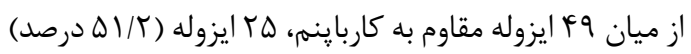

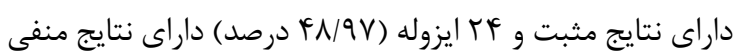

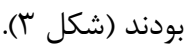

تعيين هويت ايزولههاى سودوموناس آئروزينوزا به روش

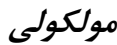
در اين مطالعه جهت افزايش دقت و صحت در تشخيص

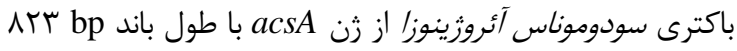

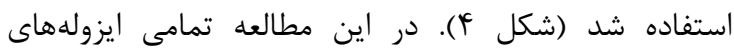

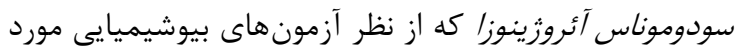

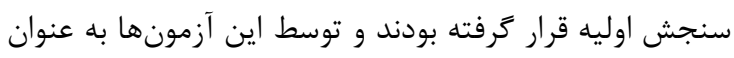

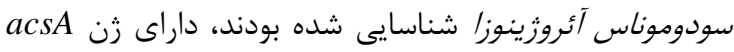




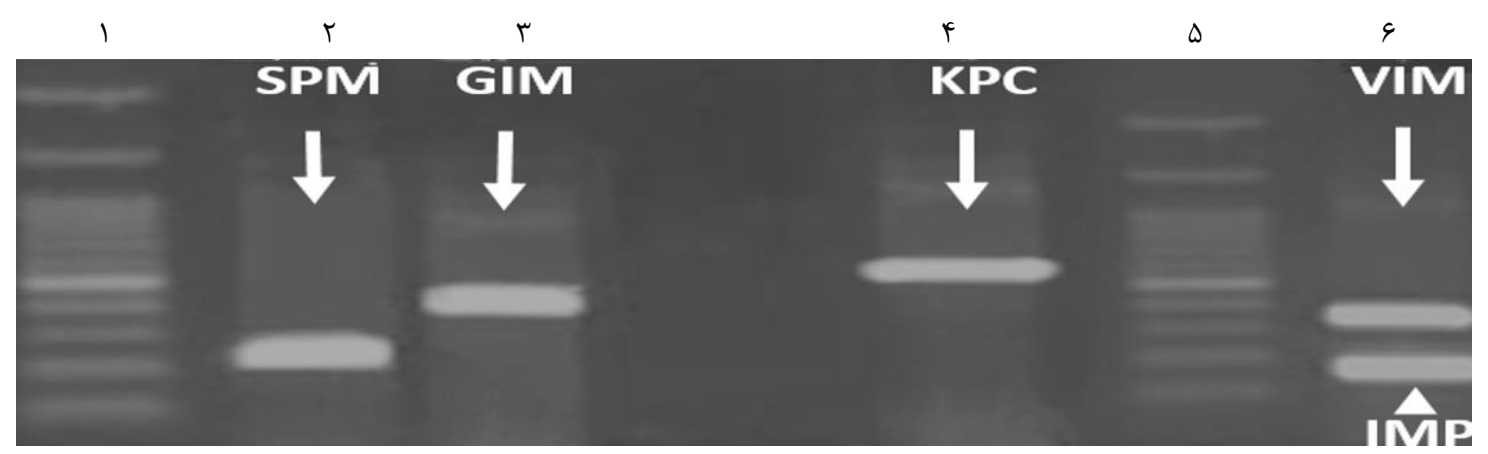

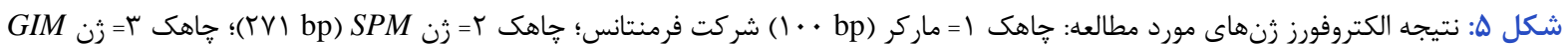

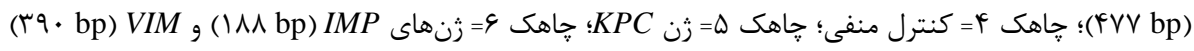

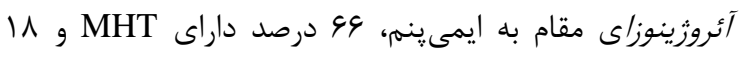

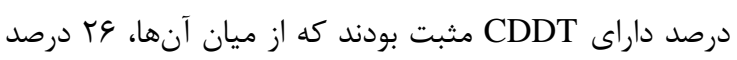

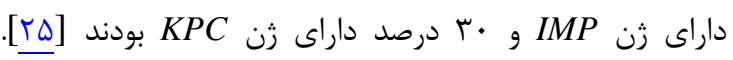
سويههاى MHT و

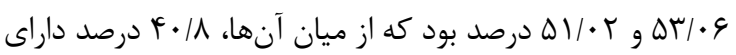



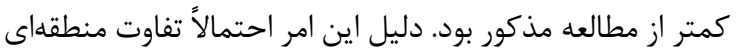

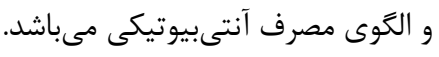

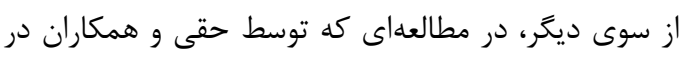

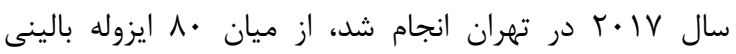

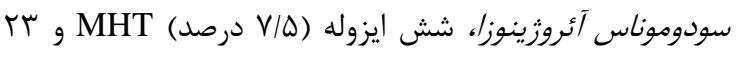

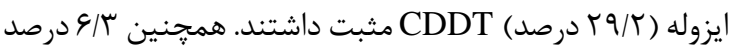



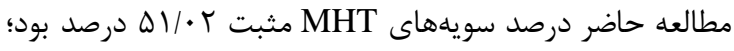

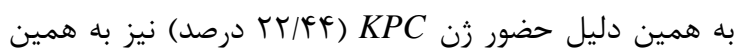
ميزان بالاتر از مطالعه حقى بود.

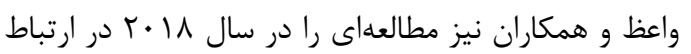

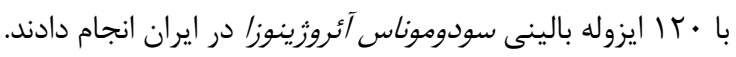

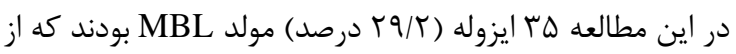

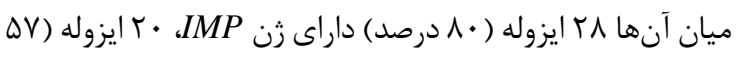

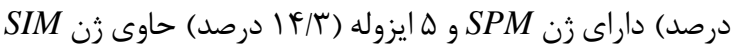

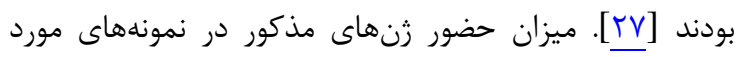

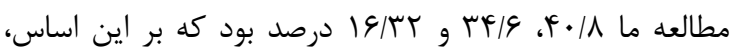



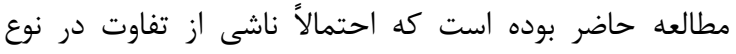

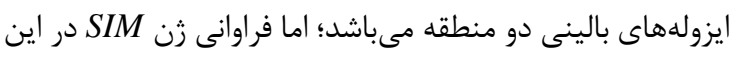
دو مطالعه بسيار نزديك به يكديگر بود. همجنين در مطالعهاى كه توسط وحدانى و همكاران در سال

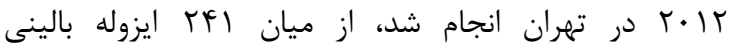

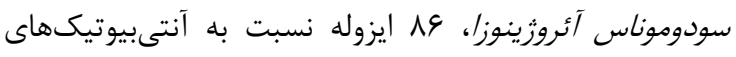
كارباينم مقاوم بودند كه از اين ميان، VD ايزوله

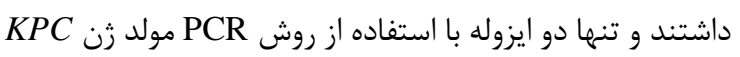

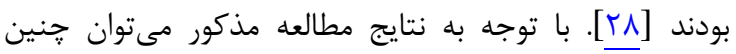

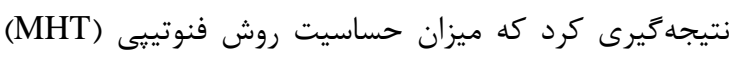

در اين راستا، در مطالعهاى كه توسط سياسى و همكاران در

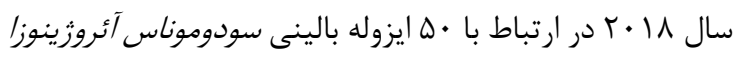

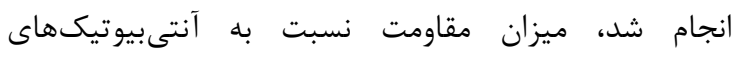

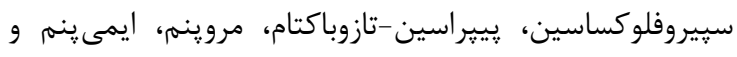

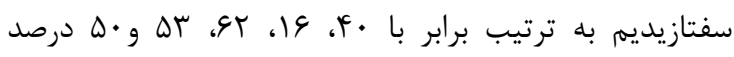

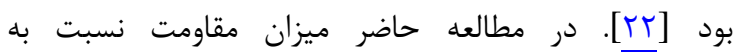
آنتى بيوتيكهاى مذكور

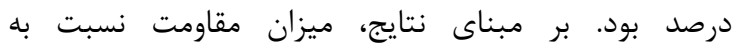
آنتىبيوتيكهاى سييروفلوكساسين و و يِييراسيلين-تازوباكتام

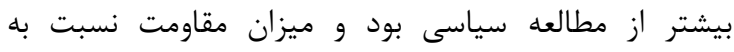

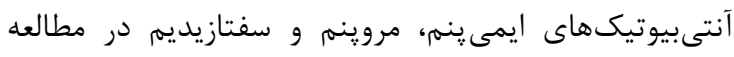



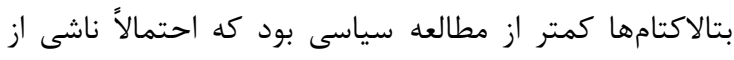

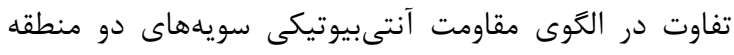
مى باشد. - معاو

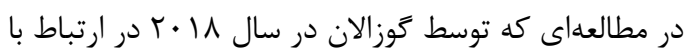
اله ايزوله بالينى سودوموناس آئروزينوزا در كشور تركيه انجام

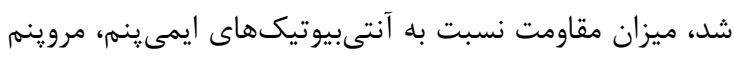

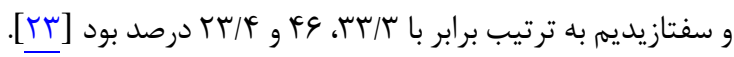

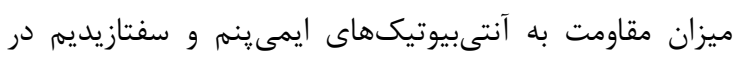



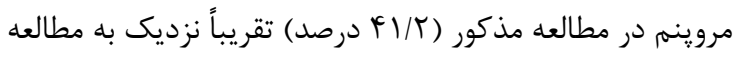

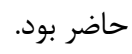

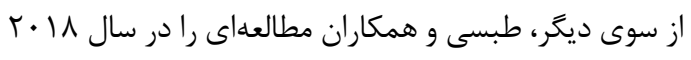

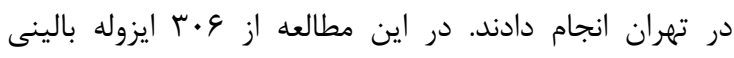

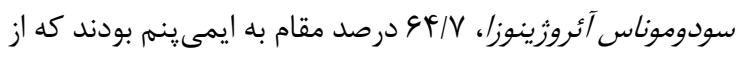

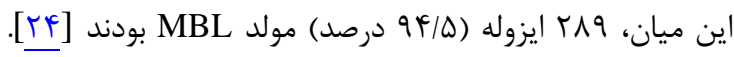
ميزان مقاومت آنتىبيوتيكى به ايمى ينم

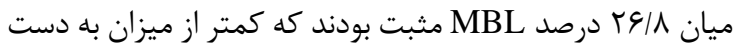

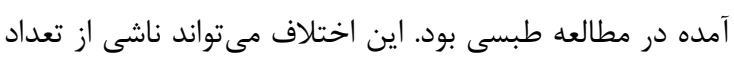

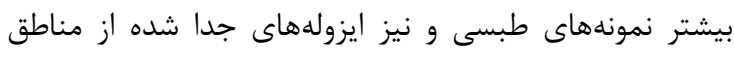
جغرافيايى مختلف باشد. همجنين در مطالعهاى كه توسط احمد و همكاران در سال

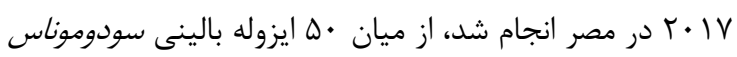




$$
\text { انجام اين مطالعه ابراز مىنمايند. }
$$

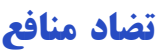

بين نتايج مطالعه و منافع نويسندگان هيجزونه تعارضى

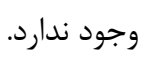

\section{ملاحظات اخلاقى}

اين مطالعه داراى تأييديه از كميته اخلاق دانشگاه علوم يزشكى همدان با كد IR.UMSHA.REC.1396.662 مى إسباشد.

سهم نويسندكان

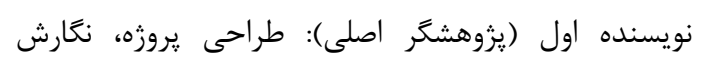

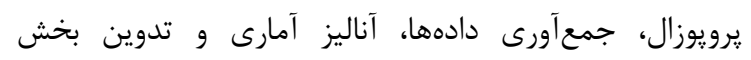

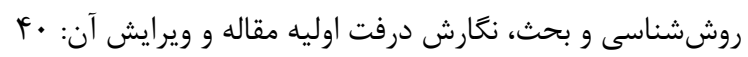

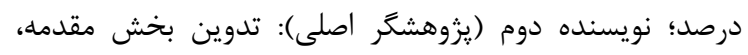

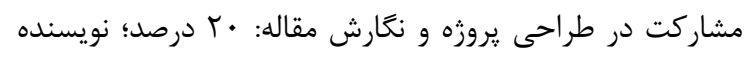

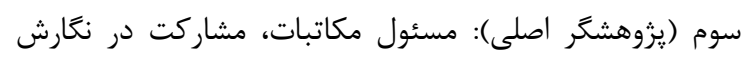

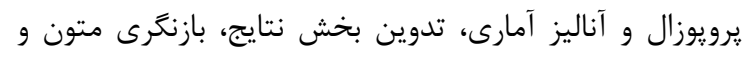
نغارش مقاله: · • ب درصد.

$$
\begin{aligned}
& \text { حمايت مالى } \\
& \text { اين يروزه با حمايت مالى معاونت تحقيقات و فناورى دانشعاه } \\
& \text { علوم يزشكى همدان انجام شده است. }
\end{aligned}
$$

\section{REFERENCES}

1. Potron A, Poirel L, Nordmann P. Emerging broad-spectrum resistance in Pseudomonas aeruginosa and Acinetobacter baumannii: mechanisms and epidemiology. Int J Antimicrob Agents. 2015;45(6):568-85. PMID: 25857949 DOI: 10.1016/ j.ijantimicag.2015.03.001

2. Wolter DJ, Lister PD. Mechanisms of beta-lactam resistance among Pseudomonas aeruginosa. Curr Pharm Des. 2013; 19(2):209-22. PMID: 22894618

3. Driscoll JA, Brody SL, Kollef MH. The epidemiology, pathogenesis and treatment of Pseudomonas aeruginosa infections. Drugs. 2007;67(3): 351-68. PMID: 17335295 DOI: $10.2165 / 00003495-200767030-00003$

4. Öztürk H, Ozkirimli E, Özgür A. Classification of Betalactamases and penicillin binding proteins using ligandcentric network models. PloS One. 2015;10(2):e0117874. PMID: 25689853 DOI: 10.1371/journal.pone.0117874

5. Shaikh S, Fatima J, Shakil S, Rizvi SMD, Kamal MA. Antibiotic resistance and extended spectrum beta-lactamases: Types, epidemiology and treatment. Saudi J Biol Sci. 2015;22(1):90-101. PMID: 25561890 DOI: 10.1016/j.sjbs. 2014.08.002

6. Pang Z, Raudonis R, Glick BR, Lin TJ, Cheng Z. Antibiotic resistance in Pseudomonas aeruginosa: mechanisms and alternative therapeutic strategies. Biotechnol Adv. 2018; 37(1):177-92. PMID: 30500353 DOI: 10.1016/j.biotechadv. $\underline{2018.11 .013}$

7. Sujatha R, Goyal R, Mishra V. Detection of metallo beta lactamase producing pseudomonas aeruginosa among clinical isolates. Int J Curr Microbiol App Sci. 2017; 6(2):1567-73. DOI: 10.20546/ijcmas.2017.602.175

8. Pathak P, Jaishi N, Yadav BK, Shah PK. Prevalence of extended spectrum beta lactamases (ESBL) and metallo beta lactamases (MBL) mediated resistance in gram negative bacterial pathogens. Tribhuvan Univ J Microbiol. 2017; 4(1):49-54.

$$
\begin{aligned}
& \text { نسبت به روش PCR يايين بوده است؛ بنابراين جهت تأييد }
\end{aligned}
$$

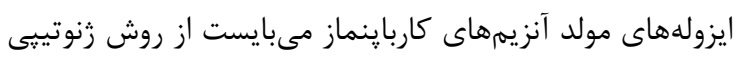



$$
\begin{aligned}
& \text { نتيجه تيرى } \\
& \text { مىتوان קنين استنتاج نمود كه توانايى توليد آنزيمهاى }
\end{aligned}
$$

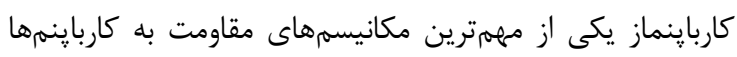

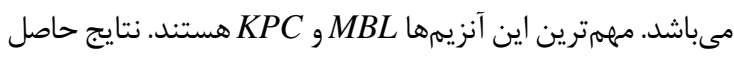

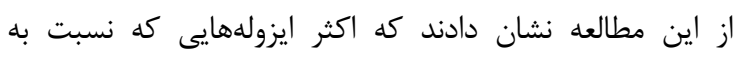

$$
\begin{aligned}
& \text { آنتىبيوتيكهاى كارباينم مقاوم بودند، داراى زنهاى دائ }
\end{aligned}
$$

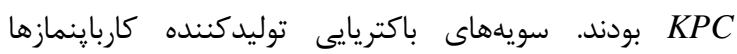

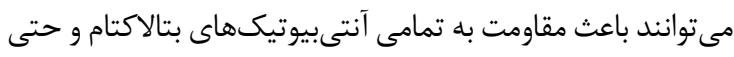

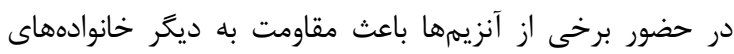

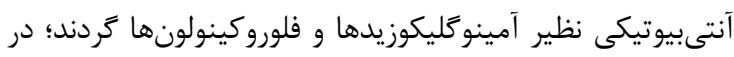

$$
\begin{aligned}
& \text { نتيجه درمان اين عفونتها به عنوان يك مشكل مهرم در مرئين مراكز } \\
& \text { بهداشتى - درمانى مطرح مىباشد. } \\
& \text { تشكر و قدرداذى } \\
& \text { اين مقاله بركرفته از يايانامه دوره كارشناسى ارشد }
\end{aligned}
$$

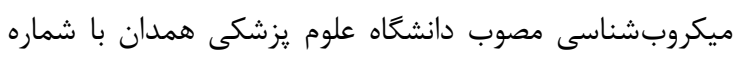



$$
\begin{aligned}
& \text { قدردانى خود را از معاونت محترم تحقيقات و فناورى و كاركنان }
\end{aligned}
$$

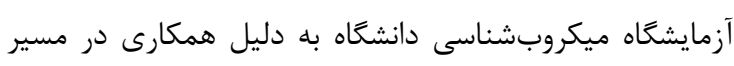

9. Amini K, Mobasseri P. Detection rate of metallo- $\beta$ lactamase-expressing genes; blaVIM-1, blaVIM-2 and blaSPM-1 in Pseudomonas aeruginosa isolates. Int J Basic Sci Med. 2017;2(1):41-5. DOI: 10.15171/ijbsm.2017.09

10. Galvani AA, Tukmechi A. Determination of the prevalence of metallo- $\beta$-lactamases producing Pseudomonas aeruginosa strains from clinical samples by imipenem-EDTA combination disk method in Mottahari and Emam Khomaini hospitals of Urmia. Rep Health Care. 2015;1(2):65-8.

11. Clinical and Laboratory Standards Institute. Performance standards for antimicrobial susceptibility testing. Wayne, PA: Clinical and Laboratory Standards Institute; 2018. P. 38-40.

12. Humphries RM, Hindler JA, Magnano P, Wong-Beringer A, Tibbetts R, Miller SA. Performance of ceftolozanetazobactam Etest, MIC test strips and disk diffusion as compared to reference broth microdilution for beta-lactam resistant Pseudomonas aeruginosa isolates. J Clin Microbiol. 2017;56(3):e01633-17. PMID: 29212704 DOI: $10.1128 /$ JCM.01633-17

13. Pasteran F, Veliz O, Faccone D, Guerriero L, Rapoport M, Mendez T, et al. A simple test for the detection of KPC and metallo- $\beta$-lactamase carbapenemase-producing Pseudomonas aeruginosa isolates with the use of meropenem disks supplemented with aminophenylboronic acid, dipicolinic acid and cloxacillin. Clin Microbiol Infect. 2011;17(9):1438-41. PMID: 21689207 DOI: 10.1111/j.1469-0691.2011.03585.x

14. Carvalhaes CG, Picão RC, Nicoletti AG, Xavier DE, Gales AC. Cloverleaf test (modified Hodge test) for detecting carbapenemase production in Klebsiella pneumoniae: be aware of false positive results. J Antimicrob Chemother. 2009; 65(2):249-51. PMID: 19996141 DOI: 10.1093/jac/dkp431

15. Doumith M, Ellington MJ, Livermore DM, Woodford N. Molecular mechanisms disrupting porin expression in ertapenem-resistant Klebsiella and Enterobacter spp. clinical isolates from the UK. J Antimicrob Chemother. 2009; 
63(4):659-67. PMID: 19233898 DOI: 10.1093/jac/dkp029

16. Honda K, Muramatsu H, Yano S, Ishizawa F, Iwabuchi Y, Sugano Y. Purification and concentration of DNA using 1fucose-specific lectin. Forensic Sci Int Genet Suppl Ser. 2017;6:e177-9. DOI: 10.1016/j.fsigss.2017.09.074

17. Cheruvanky A, Stoesser N, Sheppard AE, Crook DW, Hoffman PS, Weddle E, et al. Enhanced Klebsiella pneumoniae carbapenemase (KPC) expression from a novel Tn4401 deletion. Antimicrob Agents Chemother. 2017; 61(6):e00025-17. PMID: 28373185 DOI: 10.1128/AAC. 00025-17

18. Wang TH, Leu YS, Wang NY, Liu CP, Yan TR. Prevalence of different carbapenemase genes among carbapenemresistant Acinetobacter baumannii blood isolates in Taiwan. Antimicrob Resist Infect Control. 2018;7:123. PMID: 30338061 DOI: $10.1186 / \mathrm{s} 13756-018-0410-5$

19. Ellington MJ, Kistler J, Livermore DM, Woodford N. Multiplex PCR for rapid detection of genes encoding acquired metallo- $\beta$-lactamases. J Antimicrob Chemother. 2006; 59(2):320-2. PMID: 17185300 DOI: $10.1093 / \mathrm{jac} / \mathrm{dkl} 481$

20. Gardner JG, Grundy FJ, Henkin TM, Escalante-Semerena JC. Control of acetyl-coenzyme A synthetase (AcsA) activity by acetylation/deacetylation without NAD+ involvement in bacillus subtilis. J Bacteriol. 2006;188(15):54-60. PMID: 16855235 DOI: $10.1128 /$ JB.00215-06

21. Livermore DM. Interplay of impermeability and chromosomal beta-lactamase activity in imipenem-resistant Pseudomonas aeruginosa. Antimicrob Agents Chemother. 1992;36(9):2046-8. PMID: 1329641 DOI: 10.1128/aac.36.9.2046

22. Siasi E, Rafiei Tabatabaii R, Moslehimehr F. Isolation of bla_vim gene in Antibiotic resistant Pseudomonas aeruginosa from hospitals. Cell Mol Biol J. 2018;8(29):97106. [Persian]

23. Gozalan A, Coskun-Ari FF, Ozdem B, Unaldi O, Celikbilek $\mathrm{N}$, Kirca F, et al. Molecular characterization of vancomycinresistant Enterococcus faecium strains isolated from carriage and clinical samples in a tertiary hospital, Turkey. $J$ Med Microbiol. 2015;64(7):66-75. PMID: 25976005 DOI: 10.1099/jmm.0.000088

24. Tabasi M, Azizian R, Eskandarion MR, Habibi M, Asadi Karam MR. Detection of Metallo- $\beta$-Lactamases (MBLs) producing Pseudomonas aeruginosa isolates in Tehran hospitals, Iran. J Med Microbiol Infect Dis. 2017;5(3):47-50. DOI: 10.29252/JoMMID.5.3.4.47

25. Ahmed OM, Manal AA, Samia AG. Evaluation of a new phenotypic method to screen for OprD-deficient mutant strains of Pseudomonas aeruginosa. Int J Curr Microbiol App Sci. 2017;6(2):1894-901.

26. Haghi F, Keramati N, Hemmati F, Zeighami H. Distribution of integrons and gene cassettes among metallo- $\beta$-lactamase producing Pseudomonas aeruginosa clinical isolates. Infect Epidemiol Microbiol. 2017;3(2):36-40. DOI: 10.18869/ modares.iem.3.2.36

27. Vaez H, Khademi F, Salehi-Abargouei A, Sahebkar A. Metallo-beta-Lactamase-producing Pseudomonas aeruginosa in Iran: a systematic review and meta-analysis. Infez Med. 2018;26(3):216-25. PMID: 30246764

28. Vahdani M, Azimi L, Asghari B, Bazmi F, Rastegar Lari A. Phenotypic screening of extended-spectrum $\beta$-lactamase and metallo- $\beta$-lactamase in multidrug-resistant Pseudomonas aeruginosa from infected burns. Ann Burns Fire Disasters. 2012;25(2):78-81. PMID: 23233825 